\title{
Effects of plant growth regulators, carbon sources and pH values on callus induction in Aquilaria malaccensis leaf explants and characteristics of the resultant calli
}

\begin{abstract}
The endangered tropical tree, Aquilaria malaccensis, produces agarwood for use in fragrance and medicines. Efforts are currently underway to produce valuable agarwood compoundsn tissue culture. The purpose of this study was to develop an optimal growth medium, specifically, the best hormone combination for callus suspension culture. Using nurserygrown A. malaccensis, sterilized leaf explants were first incubated on basic Murashige and Skoog (MS) gel medium containing 15g/L sucrose and at $\mathrm{pH}$ 5.7. Different auxin types including 1-naphthaleneacetic acid (NAA), 2,4-dichlorophenoxyacetic acid (2,4-D), and indole-3-butyric acid (IBA), were tested at various concentrations $(0.55,1.1$ and $1.65 \mu \mathrm{M})$ using the basic medium. Leaf explants were incubated for 30 days in the dark. Callus induced by $1.1 \mu \mathrm{M}$ NAA had the highest biomass dry weight (DW) of $17.3 \mathrm{mg}$; however the callus was of a compact type. This auxin concentration was then combined with either 6benzylaminopurine (BAP) or kinetin at $0.55,1.1,2.2$ or $3.3 \mu \mathrm{M}$ to induce growth of friable callus. The $1.1 \mu \mathrm{M}$ NAA $+2.2 \mu \mathrm{M}$ BAP combination produced friable callus with the highest biomass (93.3mg DW). When testing the different carbon sources and $\mathrm{pHs}$, sucrose at $15 \mathrm{~g} / \mathrm{L}$ and $\mathrm{pH}$ at 5.7 yielded highest biomasses at $87.7 \mathrm{mg}$ and $83 \mathrm{mg} \mathrm{DW}$, respectively. Microscopic observations revealed the arrangement of the friable cells as loosely packed with relatively large cells, while for the compact callus, the cells were small and densely packed. We concluded that MS medium containing $15 \mathrm{~g} / \mathrm{L}$ sucrose, $1.1 \mu \mathrm{M}$ NAA $+2.2 \mu \mathrm{M}$ BAP hormone combination, and a $\mathrm{pH}$ of 5.7 was highly effective for inducing friable callus from leaf explants of A. malaccensis for the purpose of establishing cell suspension culture.
\end{abstract}

Keyword: Agarwood; Endangered tree; In vitro; Plant growth regulators; Thymelaeaceae 